\title{
Effect of Different Sowing Dates on Cotton (Gossypium hirsutum L.) Fiber Color at Double Crop Growing Conditions
}

\author{
Osman ÇOPUR ${ }^{1 *}$, Davut POLAT ${ }^{2}$, Ceren ODABAŞIOĞLU ${ }^{1}$ \\ ${ }^{1}$ Department of Field Crops, Faculty of Agriculture, Harran University, Sanliurfa, Turkey \\ [ORCID:https://orcid.org/0000-0003-1043-9394] (O. ÇOPUR), 0000-0002-0552-3113 (C. ODABAŞIOĞLU)] \\ ${ }^{2}$ Department of Field Crops, Graduate School of Natural and Applied Sciences, Harran University, 63190 \\ Şanlıurfa Turkey \\ [ORCID:https://orcid.org/0000-0002-4702-9367] \\ "Corresponding author: ocopur@harran.edu.tr
}

\begin{abstract}
Cotton fiber color is determined by the effect of fiber reflectance (Rd) and fiber yellowness ( $+b)$, which are important standards for determining cotton price. This study was conducted to determine effects of different sowing times on fiber color components in widely grown four cotton (Gossypium hirsutum L.) varieties in 2015 and 2016 under Harran Plain double crop conditions. The experiments were conducted on the experimental area of Agricultural Faculty of Harran University at Eyyübiye Campus. Seeds of cotton cultivars were sown according to sowing dates with completely randomized split plot experimental design with three replications. Sowing dates (June $1^{\text {st }}$, June $10^{\text {th }}$ and June $20^{\text {th }}$ ) were kept in main plot and varieties (Stoneville 468, BA 119, DP 499 and PG 2018) were in sub plot. Four cotton varieties (Stoneville 468, BA 119, DP 499 and PG 2018), which are certified for Harran Plain, were used as plant material. As the result of the study, the fiber color of Şanlıurfa province, where all varieties are in the light and white class according to the $\mathrm{HVI}$ color scale, but white color is changing from standard 2 to standard 3 and standard 4 grade. All the varieties used in the experiment were affected by sowing time in terms of fiber color and whiteness of color was found to be dulled with the delay in the sowing time. For this reason, early and late harvests should not be mixed and should be stored separately.
\end{abstract}

Key Words: Cotton, Sowing date, Cultivars, Color grade

\section{İkinci Ürün Koşullarında Farklı Ekim Zamanlarının Pamuk (Gossypium hirsutum L.) Lif Rengine Etkisi}

Öz

Lif parlaklığı (Rd) ve lif sarılı̆̆ı (+b) etkisiyle belirlenen lif rengi (CG), pamuk fiyatını belirleyen önemli özelliklerdir. Bu araştırma, Harran Ovası 2. ürün koşullarında farklı ekim zamanlarında yaygın olarak üretimi yapılan 4 pamuk (Gossypium hirsutum L.) çeşidinde lif rengine olan etkisini belirlemek amacıyla 2014 ve 2015 yıllarında yürütülmüştür. Çalışma, Harran Üniversitesi Ziraat Fakültesi Eyyübiye Kampüsü araştırma alanında, bölünmüş parseller deneme desenine göre; ekim zamanları ana parselleri (1 Haziran, 10 Haziran ve 20 Haziran) ve çeşitler ise alt parselleri (STV-468, BA-119, DP-499 ve PG-2018) oluşturacak şekilde 3 tekerrürlü olarak yürütülmüştür. Denemede kullanılan pamuk çeşitleri bölgemizde tescilli olan çeşitlerdir. Çalışma sonucunda, lif parlaklığı ve lif sarılı̆̆ının çeşitler ve ekim zamanına göre farklıık göstermekle birlikte, HVI renk skalasına göre tüm çeşitlerin parlak ve beyaz sınıfında yer aldığı, Şanlıurfa iline ait lif renginin, ekim zamanının gecikmesiyle beyaz sınıfa ait standart-2 derecesinden standart 3 ve standart 4 renk aralığına doğru değiştiği saptanmıştır. Denemede kullanılan tüm çeşitlerin lif rengi yönünden ekim zamanlarından etkilendiği ve ekimin gecikmesiyle rengin hafif matlaştığı, bu amaçla, erken ve geç ekilen pamukların birbirine karıştııımaması ve farklı depolarda depolanması gerektiği saptanmıştır.

Anahtar Kelimeler: Pamuk, Ekim zamanı, Çeşitler, Lif rengi 


\section{Introduction}

Cotton fiber is the basic raw material in the textile industry, and cotton is an important plant for Turkey's agriculture and trade due to its health properties. One of the properties that indicate the quality of fiber is its color. These properties include fiber reflectance and yellowness, and the negative relationship between these two properties and the environmental effects give the fiber its color. Cotton fiber color is important in that it determines the suitability of yarn and fabric for dyeing and the bleaching ratio (Güvercin, 2016).

Cotton lint color is defined by fiber reflectance and fiber yellowness, and it is one of the most important properties that determine the price of cotton. Standardization is accepted as the key to competition in the textile market in developed countries. The fiber color of Gossypium hirsutum L. is determined using the Nickerson-Hunter scale. The intersection point of reflectance (Rd) and yellowness $(+b)$ grades on this scale is detected by a HVI (High Volume Instruments) device and encoded as the fiber color. The first digit of the color code indicates the color grade, whereas the second digit indicates the color class.

While cotton fiber color is defined by the genetic structure of a given species, it is also affected by environmental conditions. While the genetic structure leads to various colors such as brown, tan, green, and mostly white in cotton fiber, environmental factors such as field conditions, precipitation, biotic stress, and storage may cause deterioration in fiber color and difficulties in dyeing and finishing operations. When fibers of Gossypium hirsutum L., which is the most widely traded cotton variety in the world and has a white fiber color, are exposed to sunlight for prolonged periods of time, they lose their reflectance. Fibers exposed to too much precipitation, the color turns gray, fibers affected by diseases and pests have a yellowish color, and fibers exposed to humidity have a gray-bluish color due to fermentation. This leads to cotton described as "lightly spotted", "spotted", "colored", "yellow stained", and "gray".

Turkey is an important cotton producer, and cotton cultivation is done three regions with different ecological properties. According to studies in these three regions known as the Mediterranean Region, the Aegean Region and the Southeastern Anatolia Region, cotton fibers in the Aegean Region have higher reflectance compared to those in the Mediterranean Region and location affects fiber properties (Cengiz, 2004), whereas some researchers report that regional conditions do not affect fiber color (Borzan et al., 2003). While it is reported that fibers in the Kahramanmaras province are in the 31-2 color range of the standard-1 grade (Denizdurduran, 2008), Kılınçkıran and Onat (2003) report that these fibers are in the light spotted grade. On the other hand, one study reports Lachata and SG 501 varieties have similar fiber reflectance $\mathbf{7 8 . 3 7 \%}$ and $78.75 \%$ respectively) and different 
fiber yellowness $(7.75 \%$ and $8.28 \%$ respectively) under Harran Plain conditions (Ogur, 2000), whereas other studies report no difference in terms of fiber reflectance, yellowness, and color under the same conditions (Birgül, 2008). Further, it is reported that fiber colors in three different harvest times in Harran Plain varied between standard guarantee-1 (21-2) and standard-3 (41-1) of the white grade (Birgül, 2008) and genetic structure is more important in terms of fiber reflectance (Kanadıkırık, 2003) compared to sowing time (Ataş, 2008).

Sowing time is a factor that affects environmental conditions, and it is reported in numerous studies that sowing time practices affect fiber reflectance and fiber yellowness particularly in case of late sowing (Pettigrew et al., 2009). While Bradow and Bauer (1997) report that total temperature affects fiber reflectance positively and fiber yellowness negatively, Aguiar et al. (2007) report that fiber properties are managed by additive gene action and the heterosis value for these properties may be small (5-10\%) and both positive and negative.

This study aims to determine effects of different sowing times on fiber colors of certified and grown cotton varieties in Harran Plain under double crop conditions, minimize product loss in fiber cotton storage, and contribute to studies on this subject.

\section{Material and Methods}

Field trials were carried out on a claytextured soil (vertic calciorthid aridisol) during the 2014 and 2015 double crop cotton-growing seasons at Faculty of Agriculture Research and Application Centre of Harran University located in Şanlıurfa, Turkey. The experimental site is located in Harran Plain (altitude: 465 $\mathrm{m} ; 37^{\circ} 08^{\prime}$ North and $38^{\circ} 46^{\prime}$ East), near to the Turkish-Syrian border. The soil texture was of clay loam-type. Average field capacity, permanent wilting point, dry bulk density and $\mathrm{pH}$ of the site at 90 $\mathrm{cm}$ soil depth were $32 \%, 22 \%, 1.41 \mathrm{~g} \mathrm{~cm}^{-3}$ and 7.2 , respectively (Tab. 1). The average air temperatures were in $12{ }^{\circ} \mathrm{C}$ $32{ }^{\circ} \mathrm{C}$ range during the double crop cotton growing season, while relative humidity was below $50 \%$ in June, July and August for the both treatment years (Tab. 2). After the wheat had been harvested, the tillage was done in the trial area and the seeds of the cotton were drilled and then the trial area was irrigated by sprinkler system according to sowing times. In the scope of the study, seeds of cotton cultivars were sown according to sowing dates with the randomized complete split plot experimental design with three replications. Sowing dates (June $1^{\text {st }}$, June $10^{\text {th }}$ and June $20^{\text {th }}$ ) were kept in main plot and varieties (Stoneville 468, BA 119, DP 499 and PG 2018) were in sub plot and a material widely cultivated in 
southeast of Turkey. The plots consisted of four rows, $10 \mathrm{~m}$ in length with interrow spacing of $0.70 \mathrm{~m}$ and intra-row spacing of $0.15-0.20 \mathrm{~m}$; oriented in south-north direction; and hand-thinned to 5 to 6 plants per meter row when the seedlings had approximately three true leaves. The cotton was planted in each plot at $40-50 \mathrm{~mm}$ depth by an experimental driller on June $1^{\text {st }}$, June $10^{\text {th }}$, and June $20^{\text {th }}, 2014$ and 2015. Preplant fertilizer was applied at a rate of 70 $\mathrm{kg} \mathrm{N} \mathrm{ha}{ }^{-1}$ and $70 \mathrm{~kg} \mathrm{P} \mathrm{ha}^{-1}$ as 20-20-0 fertilizer and followed by $90 \mathrm{~kg} \mathrm{ha}^{-1} \mathrm{~N}$ as $46 \%$ urea applied at the initiation of flowering. $\mathrm{K}_{2} \mathrm{O}$ was not applied due to its abundance in the soil. Soil tillage and other cultural practices (hoeing, weeding, pest management and irrigation) were used, as needed, according to recommendations of the regional agricultural experimental station.
A 2-m border spacing was left between blocks to reduce edge effects. Seed cotton samples were handharvested from all plants, from 10-m sections of the four middle rows in each four row plot. The first hand-picking was done on October $23^{\text {rd }}, 2014$ and October $15^{\text {th }}, 2015$, and the second hand-picking was done on November $6^{\text {th }}, 2014$ and November $4^{\text {th }}, 2015$. Approximately a 300-g seed cotton sample collected from each plot was ginned to determine lint color grade (CG), reflectance $(+R d)$, yellowness $(+b)$ and fiber maturity. Fiber tests were conducted at a relative humidity of $65 \pm 2 \%$ and a temperature of $20 \pm 1{ }^{\circ} \mathrm{C}$ to determine lint color grade $(C G)$, reflectance $(+R d)$, yellowness $(+b)$ and fiber maturity were measured by High Volume Instrument (HVI-1000) test device.

Table 1. Some soil properties of the study area (Research Station of Harran University, Şanlıurfa, Turkey) (Anonymous, 2006)

Çizelge 1. Deneme alanının bazı toprak özellikleri (Harran Üniversitesi Araştırma İstasyonu, Şanlıurfa,

\begin{tabular}{|c|c|c|c|c|c|c|c|c|c|c|c|}
\hline \multirow[t]{2}{*}{$\begin{array}{l}\text { Depth } \\
\text { (Derinlik) } \\
\text { (cm) }\end{array}$} & \multirow[t]{2}{*}{$\begin{array}{c}\mathrm{BD} \\
\mathrm{HA} \\
\left(\mathrm{g} \mathrm{cm}^{-3}\right)\end{array}$} & \multirow[t]{2}{*}{$\begin{array}{l}\text { OM } \\
(\%)\end{array}$} & \multicolumn{3}{|c|}{$\begin{array}{l}\text { Soil particle distribution } \\
\text { Toprak partiküllerinin dağ. } \\
(\%)\end{array}$} & \multirow[t]{2}{*}{$\mathrm{pH}$} & \multirow[t]{2}{*}{$\begin{array}{c}\mathrm{N} \\
\left(\mathrm{kg} \mathrm{ha}^{-1}\right)\end{array}$} & \multirow[t]{2}{*}{$\begin{array}{c}\mathrm{P}_{2} \mathrm{O}_{5} \\
\left(\mathrm{~kg} \mathrm{ha}^{-1}\right)\end{array}$} & \multirow[t]{2}{*}{$\begin{array}{c}\mathrm{K}_{2} \mathrm{O} \\
\left(\mathrm{kg} \mathrm{ha}^{-1}\right)\end{array}$} & \multirow[t]{2}{*}{$\begin{array}{c}\mathrm{FC} \\
\mathrm{TK} \\
(\%)\end{array}$} & \multirow[t]{2}{*}{$\begin{array}{l}\text { PWP } \\
\text { SSN } \\
(\%)\end{array}$} \\
\hline & & & $\begin{array}{l}\text { Sand } \\
\text { Kum }\end{array}$ & $\begin{array}{l}\text { Silt } \\
\text { Silt }\end{array}$ & $\begin{array}{l}\text { Clay } \\
\text { Kil }\end{array}$ & & & & & & \\
\hline $0-30$ & 1.37 & 1.2 & 7 & 34 & 59 & 7.3 & 25 & 27 & 1280 & 31.5 & 22.2 \\
\hline $30-60$ & 1.40 & 0.8 & 17 & 25 & 58 & 7.2 & 12 & 20 & 900 & 31.8 & 22.6 \\
\hline $60-90$ & 1.43 & 0.6 & 20 & 21 & 59 & 7.2 & 6 & 17 & 810 & 32.3 & 21.5 \\
\hline $90-120$ & 1.43 & 0.5 & 19 & 20 & 62 & 7.2 & - & - & - & 32.5 & 21.5 \\
\hline
\end{tabular}


Table 2. Climatic data of the study area during double crop cotton crop growing season for 2014 and 2015 years (Anonymous, 2016)

Çizelge 2. 2014 ve 2015 yıllarında ikinci ürün pamuk yetiştirme sezonunda bazı iklim özellikleri

\begin{tabular}{|c|c|c|c|c|c|c|}
\hline & $\begin{array}{l}\text { June } \\
\text { Haziran }\end{array}$ & $\begin{array}{c}\text { July } \\
\text { Temmuz }\end{array}$ & $\begin{array}{l}\text { August } \\
\text { Ağustos }\end{array}$ & $\begin{array}{l}\text { September } \\
\text { Eylül }\end{array}$ & $\begin{array}{l}\text { October } \\
\text { Ekim }\end{array}$ & $\begin{array}{l}\text { November } \\
\text { Kasım }\end{array}$ \\
\hline \multicolumn{7}{|c|}{2014} \\
\hline Min. air temp. $\left({ }^{\circ} \mathrm{C}\right)$ & 15.3 & 20.3 & 20.2 & 14.5 & 9.5 & 4.8 \\
\hline \multicolumn{7}{|l|}{ Min. hava sıcaklığı ( $\left.{ }^{\circ} \mathrm{C}\right)$} \\
\hline Max. air temp. $\left({ }^{\circ} \mathrm{C}\right)$ & 40.1 & 43.4 & 43.5 & 40.6 & 31.9 & 22.8 \\
\hline \multicolumn{7}{|l|}{ Mak. Hava sıcaklığı $\left({ }^{\circ} \mathrm{C}\right)$} \\
\hline Average air temp. $\left({ }^{\circ} \mathrm{C}\right)$ & 28.4 & 32.5 & 32.4 & 26.2 & 20.3 & 12.1 \\
\hline \multicolumn{7}{|l|}{ Ort. hava sıcaklığı $\left({ }^{\circ} \mathrm{C}\right)$} \\
\hline Relative humidity (\%) & 43.8 & 35.2 & 38.8 & 41.0 & 49.5 & 53.9 \\
\hline \multicolumn{7}{|l|}{ Nispi nem (\%) } \\
\hline Wind speed $\left(\mathrm{ms}^{-1}\right)$ & 1.9 & 1.9 & 1.5 & 1.5 & 1.0 & 1.6 \\
\hline \multicolumn{7}{|l|}{ Rüzgar hızı $\left(m s^{-1}\right)^{\prime}$} \\
\hline Rainfall (mm) & 20.6 & --- & 1.0 & 28.8 & 25.7 & 78.6 \\
\hline \multicolumn{7}{|l|}{ Toplam yağış $(\mathrm{mm})$} \\
\hline \multicolumn{7}{|c|}{2015} \\
\hline Min. air temp. $\left({ }^{\circ} \mathrm{C}\right)$ & 16.7 & 21.4 & 22.1 & 18.7 & 12.7 & 6.8 \\
\hline \multicolumn{7}{|l|}{ Min. hava sıcaklığı ( $\left.{ }^{\circ} \mathrm{C}\right)$} \\
\hline Max. air temp. $\left({ }^{\circ} \mathrm{C}\right)$ & 38.4 & 42.8 & 43.1 & 40.4 & 33.0 & 24.3 \\
\hline \multicolumn{7}{|l|}{ Mak. hava sıcaklığı( $\left.{ }^{\circ} \mathrm{C}\right)$} \\
\hline Average air temp. $\left({ }^{\circ} \mathrm{C}\right)$ & 27.7 & 33.2 & 31.5 & 29.8 & 21.6 & 14.0 \\
\hline \multicolumn{7}{|l|}{ Ort. hava sıcaklığı $\left({ }^{\circ} \mathrm{C}\right)$} \\
\hline Relative humidity (\%) & 40.1 & 37.9 & 37.4 & 42.7 & 50.5 & 51.2 \\
\hline \multicolumn{7}{|l|}{ Nispi nem (\%) } \\
\hline Wind speed $\left(\mathrm{ms}^{-1}\right)$ & 1.9 & 1.7 & 1.6 & 1.3 & 1.4 & 1.5 \\
\hline \multicolumn{7}{|l|}{ Rüzgar hızı $\left(m^{-1}\right)^{\prime}$} \\
\hline Rainfall (mm) & 0.7 & 0.2 & --- & --- & 58.8 & 7.9 \\
\hline Toplam yağış (mm) & & & & & & \\
\hline
\end{tabular}

Statistical analysis was performed using the MSTATC statistical program (Anonymous, 1989). Means were separated using Fisher's protected least significant differences (LSD) test and $\mathrm{P}<$ 0.05 denotes the level of significance.

\section{Results and Discussion}

Fiber reflectance values obtained in different sowing times for different varieties in trial years and resulting groups can be seen in Table 3, fiber yellowness values and resulting groups can be seen in Table 4, fiber maturity values and resulting groups can be seen in Table 5, and color values can be seen in Table 6.

Table 3 shows that the fiber reflectance of cotton varieties varied between $72.28 \%$ and $74.27 \%$ in 2014 , the mean value being $72.69 \%$, and the highest fiber reflectance value was obtained for PG 2018, whereas the lowest fiber reflectance value was obtained for BA 119 . The fiber reflectance of cotton varieties varied between $72.39 \%$ and $74.50 \%$ in 2015 , the 
mean value being $73.79 \%$. The fiber reflectance varied between $72.52 \%$ and $73.47 \%$ by sowing times in 2014 , the mean value being $72.69 \%$, whereas it varied between $72.37 \%$ and $76.39 \%$ in 2015 , the mean value being $73.79 \%$. Table 3 also shows that different fiber reflectance groups formed for cotton varieties according to the LSD (Least Significant Difference) test. The variation in fiber reflectance may be due to genotypic differences or climate conditions (Birgül, 2008; Pettigrew et al., 2009). On the other hand, it was seen that the sowing time affected fiber reflectance in 2015, and the fiber reflectance decreased with the delay in sowing time. This may be due to the increase in pests or early precipitation in 2015. The classification in terms of fiber reflectance showed that the reflectance of all varieties used in the study was in the "70-80: light" group (Anonymous, 1997). This shows that all cotton varieties used in trails were suitable for use in the textile industry. These values are similar to those of Ali et al. (2009), Barradas and Bellido (2009) and Yuka (2014), who reported that the fiber reflectance varied by different sowing times and different cotton varieties.

Table 3. Fiber reflectance (Rd) values of four different cotton varieties sowed on different dates under Harran Plain conditions and resulting groups according to the Least Significant Difference (LSD) test

Çizelge 3. Harran Ovası koşullarında farklı tarihlerde ekilen dört pamuk çeşidinden elde edilen lif parlaklık değerleri ve LSD testine göre oluşna gruplar

\begin{tabular}{|c|c|c|c|c|c|c|c|c|}
\hline \multirow{5}{*}{$\begin{array}{l}\text { Cultivars } \\
\text { Çeşitler }\end{array}$} & \multicolumn{8}{|c|}{$\underline{\text { Reflectance (\%)-Parlaklık }}$} \\
\hline & \multicolumn{4}{|c|}{2014 Year $\left(Y_{\imath} l\right)$} & \multicolumn{3}{|c|}{2015 Year $(Y, I)$} & \multirow[b]{2}{*}{$\begin{array}{l}\text { Means } \\
\text { Ortalama }\end{array}$} \\
\hline & $\begin{array}{c}\text { First } \\
\text { sowing } \\
\text { date } \\
\end{array}$ & $\begin{array}{c}\text { Second } \\
\text { sowing } \\
\text { date } \\
\end{array}$ & $\begin{array}{c}\text { Third } \\
\text { sowing } \\
\text { date } \\
\end{array}$ & \multirow[t]{3}{*}{$\begin{array}{c}\text { Means } \\
\text { Ortalama }\end{array}$} & $\begin{array}{c}\text { First } \\
\text { sowing } \\
\text { date } \\
\end{array}$ & $\begin{array}{c}\text { Second } \\
\text { sowing } \\
\text { date } \\
\end{array}$ & $\begin{array}{c}\text { Third } \\
\text { sowing } \\
\text { date } \\
\end{array}$ & \\
\hline & 1.Ekim & 2. Ekim & 3. Ekim & & 1.Ekim & 2.Ekim & 3. Ekim & \\
\hline & zamanı & zamanı & zamanı & & zamanı & zamanı & zamanı & \\
\hline Stoneville 468 & 71.37 & 73.20 & 73.97 & $72.84 \mathrm{~b}$ & 77.33 & 72.30 & 73.87 & 74.50 \\
\hline BA 119 & 72.37 & 72.10 & 72.37 & $72.28 \mathrm{~b}$ & 74.30 & 70.27 & 72.60 & 72.39 \\
\hline DPL 499 & 72.73 & 71.87 & 72.73 & $72.44 \mathrm{~b}$ & 76.23 & 74.27 & 72.63 & 74.38 \\
\hline PG 2018 & 73.60 & 74.40 & 74.80 & $74.27 \mathrm{a}$ & 77.43 & 72.63 & 71.57 & 73.88 \\
\hline Grand Means & 72.52 & 72.89 & 73.47 & 72.96 & $76.33 \mathrm{a}$ & $72.37 \mathrm{~b}$ & $72.67 \mathrm{~b}$ & 73.79 \\
\hline Ortalamlar & & & & & & & & \\
\hline (C.V) (\%) & \multicolumn{4}{|c|}{1.92} & \multicolumn{3}{|c|}{2.58} & \\
\hline LSD (Varieties) & \multicolumn{3}{|l|}{1.387} & \multicolumn{5}{|c|}{ ns } \\
\hline LSD (Sowing dates) & \multicolumn{3}{|l|}{ ns } & \multicolumn{5}{|c|}{2.066} \\
\hline LSD (Varietiesx & \multirow[b]{2}{*}{ ns } & & & \multirow{2}{*}{\multicolumn{4}{|c|}{ ns }} & \\
\hline Sowing dates. & & & & & & & & \\
\hline
\end{tabular}

Table 4 shows that the fiber yellowness value of cotton varieties varied between $7.64 \%$ and $8.14 \%$ in 2014 , the mean value being $8.01 \%$, and the highest fiber yellowness value was obtained for BA 119, whereas the lowest fiber yellowness value was obtained for PG 2018. By sowing time, the fiber 
yellowness value varied between $7.73 \%$ and $8.21 \%$, the average value being 8.01\%. In 2015, on the other hand, the fiber yellowness value varied between $7.82 \%$ and $8.60 \%$, the average value being $8.22 \%$. By sowing time, the fiber yellowness value varied between $7.97 \%$ and $8.47 \%$ in 2015 , the average value being $8.22 \%$.

Table 4. Fiber yellowness (+b) values of four different cotton varieties sowed on different dates under Harran Plain conditions and resulting groups according to the Least Significant Difference (LSD) test

Çizelge 4. Harran Ovası koşullarında farklı tarihlerde ekilen dört pamuk çeşidinden elde edilen lif sarılık değerleri ve LSD testine göre oluşna gruplar

\begin{tabular}{|c|c|c|c|c|c|c|c|c|}
\hline \multirow{5}{*}{$\begin{array}{l}\text { Cultivars } \\
\text { Çeşitler }\end{array}$} & \multicolumn{8}{|c|}{ Yellowness (\%)-Sarılık } \\
\hline & \multicolumn{3}{|c|}{2014 Year $\left(Y_{I} /\right)$} & \multicolumn{5}{|c|}{2015 Year $(Y ı l)$} \\
\hline & $\begin{array}{l}\text { First } \\
\text { sowing } \\
\text { date }\end{array}$ & $\begin{array}{l}\text { Second } \\
\text { sowing } \\
\text { date }\end{array}$ & $\begin{array}{l}\text { Third } \\
\text { sowing } \\
\text { date }\end{array}$ & $\begin{array}{c}\text { Mean } \\
\text { Ortalama }\end{array}$ & $\begin{array}{l}\text { First } \\
\text { sowing } \\
\text { date }\end{array}$ & $\begin{array}{l}\text { Second } \\
\text { sowing } \\
\text { date }\end{array}$ & $\begin{array}{l}\text { Third } \\
\text { sowing } \\
\text { date }\end{array}$ & $\begin{array}{c}\text { Mean } \\
\text { Ortalama }\end{array}$ \\
\hline & 1. Ekim & 1. Ekim & 1. Ekim & & 1. Ekim & 1. Ekim & 1.Ekim & \\
\hline & zamanı & zamanı & zamanı & & zamanı & zamanı & zamanı & \\
\hline Stoneville 468 & 7.90 & 7.73 & 8.40 & 8.11 & 8.97 & 7.90 & 8.40 & $8.60 \mathrm{a}$ \\
\hline BA 119 & 7.67 & 8.03 & 8.40 & 8.14 & 8.20 & 8.43 & 8.33 & $8.06 \mathrm{bc}$ \\
\hline DPL 499 & 7.63 & 8.37 & 8.37 & 8.12 & 8.80 & 7.63 & 8.37 & $8.39 a b$ \\
\hline PG 2018 & 7.73 & 8.37 & 7.67 & 7.64 & 7.90 & 8.00 & 7.77 & $7.89 \mathrm{c}$ \\
\hline $\begin{array}{l}\text { Grand means } \\
\text { Ortalamalar }\end{array}$ & 7.73 & 8.08 & 8.21 & 8.01 & 8.47 & 7.97 & 8.22 & 8.22 \\
\hline (C.V) (\%) & & & & & & & 11 & \\
\hline LSD (Varieties) & ns & & & & & ns & & \\
\hline LSD (Çeşitler) & & & & & & & & \\
\hline LSD (Sowing dates) & & & & & & & & \\
\hline LSD (Ekmi zamanı) & ns & & & & & 0.416 & & \\
\hline LSD (Varieties $\mathrm{x}$ & & & & & & & & \\
\hline $\begin{array}{l}\text { Sowing dates. } \\
\text { LSD (Çeşitler X Ekim } \\
\text { zamanı }\end{array}$ & ns & & & & & ns & & \\
\hline
\end{tabular}

The analysis of variance showed that there was a significant difference between varieties in 2015. However, although the delay in sowing time did not affect the fiber yellowness significantly, it caused a slight increase and difference between cotton varieties in terms of fiber yellowness as seen in Table 4. Considering the mean fiber yellowness values obtained in the study, all varieties were in the " 4 - 10.5: white or slightly yellow" group (Anonymous, 1997). This may be due to the precipitation near the end of the vegetation or the underdevelopment of fibers. Ali et al. (2009) and Cao et al. (2011) had similar findings as well.

Table 5 shows that the fiber maturity value of cotton varieties varied between 0.89 and 0.94 in 2014, the mean value being 0.91 , and the highest fiber maturity value was obtained for DPL-499, whereas the lowest fiber maturity value was obtained for PG 2018. By sowing time, 
the fiber maturity value varied between 0.90 and 0.92 , the average value being 0.91. In 2015, on the other hand, the fiber maturity value varied between 0.98 and 1.05, the average value being 1.00 . By sowing time, the fiber maturity value varied between 0.98 and 1.04 in 2015, the average value being 1.00 . The analysis of variance showed that there was a significant difference between varieties by sowing time only in 2015 .

Table 5.Fiber maturity values of four different cotton varieties sowed on different dates under Harran Plain conditions and resulting groups according to the Least Significant Difference (LSD) test Çizelge 5. Harran Ovası koşullarında farklı tarihlerde ekilen dört pamuk çeşidinden elde edilen lif olgunluk değerleri ve LSD testine göre oluşan gruplar

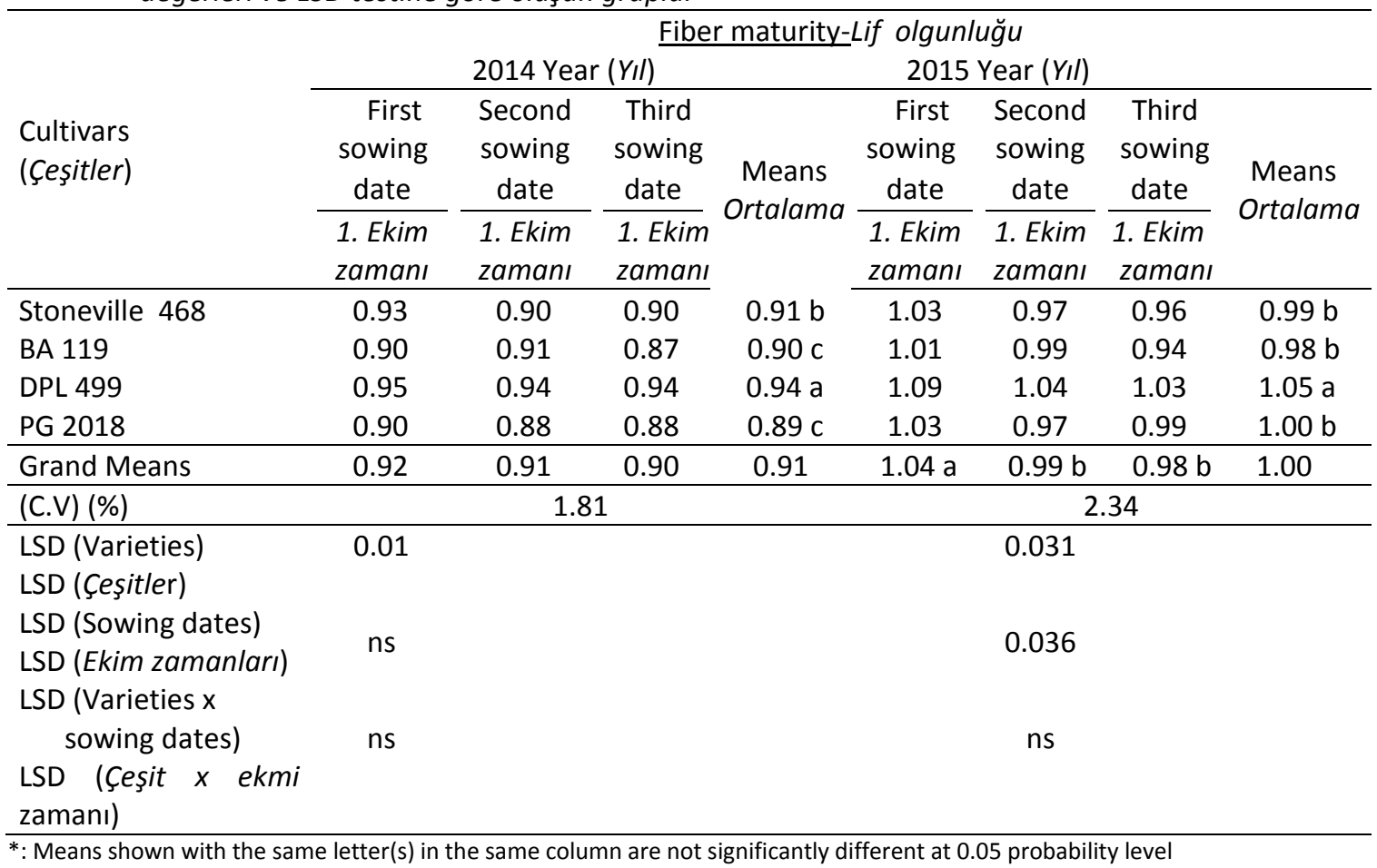

In cotton fibers, maturity is defined as a fully formed secondary wall and high fold number. Immaturity may be a result of under-development of fibers due to environmental conditions. Although the delay in sowing time did not affect the fiber maturity significantly, it caused a slight increase and difference between cotton varieties in terms of fiber maturity as seen in Table 4. Considering the mean fiber maturity values obtained in the study, all varieties were in the "0.88 -
1.09: mature and very mature" group (Anonymous, 1997).

Although cotton color is a genetic trait, it may be affected by climate conditions and soil properties as well. While it varies depending on the cotton variety and environmental conditions under normal sowing conditions, the cotton fiber color was determined to be standard white guarantee and standard one white 
Table 6. Color ranges of cotton varieties in three different sowing times under Harran Plain conditions in 2014 and 2015

Çizelge 6. 2014 ve 2015 yıllarında Harran Ovası koşullarında üç farklı ekim zamanı ve pamuk çeşitlerinde renk değişimi

\begin{tabular}{|c|c|c|c|c|c|c|}
\hline \multirow{4}{*}{$\begin{array}{l}\text { Cultivars } \\
\text { Çeşitler }\end{array}$} & \multicolumn{6}{|c|}{$\begin{array}{c}\text { Color grade } \\
\text { Renk derecesi } \\
\end{array}$} \\
\hline & \multicolumn{3}{|c|}{2014 Year $\left(Y_{I} I\right)$} & \multicolumn{2}{|c|}{2015 Year $\left(Y_{I} I\right)$} & \\
\hline & $\begin{array}{l}\text { First } \\
\text { sowing } \\
\text { date }\end{array}$ & $\begin{array}{c}\text { Second } \\
\text { sowing } \\
\text { date }\end{array}$ & $\begin{array}{c}\text { Third } \\
\text { sowing } \\
\text { date }\end{array}$ & $\begin{array}{c}\text { First } \\
\text { sowing } \\
\text { date }\end{array}$ & $\begin{array}{c}\text { Second } \\
\text { sowing } \\
\text { date }\end{array}$ & $\begin{array}{c}\text { Third } \\
\text { sowing } \\
\text { date }\end{array}$ \\
\hline & $\begin{array}{l}\text { 1. Ekim } \\
\text { zamanı }\end{array}$ & $\begin{array}{l}\text { 1. Ekim } \\
\text { zamanı }\end{array}$ & $\begin{array}{l}\text { 1. Ekim } \\
\text { zamanı }\end{array}$ & $\begin{array}{l}\text { 1. Ekim } \\
\text { zamanı }\end{array}$ & $\begin{array}{l}\text { 1. Ekim } \\
\text { zamanı }\end{array}$ & $\begin{array}{l}\text { 1. Ekim } \\
\text { zamanı }\end{array}$ \\
\hline Stoneville 468 & $31-3$ & $41-3$ & $41-4$ & $31-1$ & $31-2$ & $41-3$ \\
\hline BA 119 & $41-2$ & $41-3$ & $41-3$ & $41-1$ & $41-3$ & $41-3$ \\
\hline DPL 499 & $31-2$ & $41-3$ & $41-3$ & $31-1$ & $41-3$ & $41-4$ \\
\hline PG 2018 & $41-1$ & $41-2$ & $41-3$ & $31-2$ & $41-1$ & $41-4$ \\
\hline
\end{tabular}

Table 6 shows that the cotton varieties had different colors and the fiber color was either standard white 2 or 3 . This may be due to the color change caused by diseases and pests (especially fumagines of white flies and aphids), fiber development under low temperature conditions, or high temperature, which may affect the cotton color. For this reason, there may be a color change in mid-early and late varieties due to delayed harvest. Foreign substances in fibers may affect the color grade as well. For this reason, seed cotton from different dates and different varieties should not be mixed and stored separately.

\section{Conclusion}

In this study conducted with Stoneville 468, BA 119, DPL 499, and PG 2018 mid-early varieties under double crop conditions, while the fiber color decreased one or two grades, it was found that there was not a significant difference between the varieties. Further, sowing time did not cause a significant difference in terms of fiber reflectance, fiber yellowness, and fiber maturity values. It is recommended that seed cotton from early and late sowed crops and different varieties should be stored, ginned and baled separately.

\section{References}

Aguiar, P.A.,Penna, J.C.V., Freire, E.C., Melo, L.C., 2007. Diallel analysis of upland cotton cultivars. Crop Breeding and Applied Biotechnology 7: 353-359.

Ali, H., Afzal, M. N., Ahmad, S., Muhammad, D., 2009. Effect of cultivars and sowing dates on yield and quality of Gossypium hirsutum L. Crop. Journal of Food, Agriculture and Environment, 7 (3-4): 244247.

Anonymous, 1997. High volume instruments (HVI) catalog. Costumer information service, No: 40, Volume May, Sweden.

Anonymous, 1989. User's Guide to MSTATC, An Analysis of Agronomic Research Experiments. Michigan State University, USA.

Anonymous, 2006. Harran Plain Soil Report. Soil and Water Resources Research Institute, Şanlıurfa-Turkey. 
Anonymous, 2016. Official Record of Meteorology Directory, Şanliurfa, Turkey.

Ataş, E., 2008. Effects of Defoliation Timings on Yield and Fiber Quality of Cotton Planted at Different Dates. Çukuurova University, Graduate School of Natural and Applied Sciences, Department of Field Crops, MSc Thesis, pp:64, Adana- Turkey.

Barradas, G., Bellido, R.L., 2009. Genotype and planting date effects on cotton growth and production under South Portugal conditions, III. boll set percentage, boll location, yield and lint quality. Journal of Food and Environment, 7(2): 322-328.

Birgül, i.H., 2008. Determination of fiber characteristics for different harvesting dates and plant growth parameters in some cotton (Gossypium hirsutum L.) varieties. Harran University, Graduate School of Natural and Applied Sciences, Department of Field Crops, MSc Thesis, pp:68, Şanlıurfa- Turkey.

Borzan, G., Ersan, K., Oğlakcı, M., 2003. To compare obtained cotton (Gossypium hirsutum L.) (Upland) Aegan, Çukurova and Southeast Anatolia Regions for color grade, reflectance, preparation and standardization. $6^{\text {th }}$ Turkish Cotton, Textile and Confection Syposium Proceeding, pp: 191-198. 24- 25 April 2003, Antalya-Turkey.

Bradow, J. M.,Bauer, P J., 1997. How Variety and Weather Determine Yarn Properties and Dye Uptake. pp. 560-564. Proc. Beltwide Cotton Conf., New Orleans, LA. 7-10 Jan. 1997. National Cotton Counc.Am., Memphis, TN.

Cao, T., Oumarou, P., Gawrysiak, G., Klassou, C., Hau., B., 2011. Short season cotton (Gossypium hirsutum L.) may be a suitable response to late planting in Sub Sahara regions. Field Crops Research, 120: 9-20.

Cengiz, F., 2004. An Investigation of the physical properties of Turkish cottons and comparison with world cottons. Süleyman Demirel University, Graduate School of Natural and Applied Sciences, Department of Textile Engineering, MSc Thesis, pp:246, Isparta-Turkey.

Denizdurduran, N., 2008. The Influence of defoliation timing on yield and quality properties of cotton (G. hirsutum L.) under Kahramanmaraş conditions. Kahramanmaraş Sütçü İmam University, Graduate School of Natural and Applied Sciences, Department of Field Crops, MSc Thesis, pp:47, Kahramamaraş-Turkey.

Güvercin, R.Ş., 2016. Inheritance of reflectance and yellowness on cotton (Gossypium hirsutum L.) and effect of sowing time on heterosis and heterobeltiosis. Turkish Journal of Agricultural and Natural Sciences, 3(4): 265-271.

Kanadıkırık, B., 2003. A comparison of some cotton (Gossypium hirsutum L. ) cultivars with regard to fiber properties, trash matter and stickness under Kahramanmaraş conditions. Kahramanmaraş Sütçü İmam University, Graduate School of Natural and Applied Sciences, Department of Field Crops, MSc Thesis, pp:38, Kahramamaraş-Turkey.

Kılınçkıran, M., Onat, A., 2003. A Research on the physical characteristics of the cottons grown in Kahramanmaraş. Turkish $6^{\text {th }}$ Cotton, Textile and Readymade Symposium Proceedings, pp: 250-254. 2425 April 2003, Antalya-Turkey.

Ogur, N. Ö., 2000.Determination of defoliant application times and effects of defoliant applications on yield and quality properties of cotton in mechanical harvesting under Harran region (Gossypium hirsutum L.). Çukurova University, Graduate School of Natural and Applied Sciences, Department of Field Crops, MSc Thesis, pp:54 s. Adana-Turkey.

Pettigrew, W.T., Molin, W.T., Stetina, S.R., 2009. Impact of varying planting dates and tillage systems on cotton growth and lint yield production. Agronomy Journal, 101: 1131-1138.

Yuka, A., 2014. Determination of yield and fiber technological characters of cotton varieties (Gossypium hirsutum L.) grown as second crop after the wheat under the Harran plain ecological conditions. Harran University, Graduate School of Natural and Applied Sciences, Department of Field Crops, MSc Thesis, pp:74, ŞanlıurfaTurkey. 